\title{
Anticancer and antimicrobial activities of diosmin
}

\author{
A.C. Kilit ${ }^{1}$, E. Odabas Köse ${ }^{2}$, N. Gülmen Imir $^{3}$ and E. Aydemir ${ }^{1}$ \\ ${ }^{1}$ Department of Biology, Faculty of Science, Akdeniz University, Antalya, \\ Turkey \\ ${ }^{2}$ Medical Laboratory Program, Vocational School of Health Services, \\ Akdeniz University, Antalya, Turkey \\ ${ }^{3}$ Department of Biology Education, School of Education and Life Sciences \\ Institute, Akdeniz University, Antalya, Turkey
}

Corresponding author: A.C. Kilit

E-mail: acansukilit@gmail.com

Genet. Mol. Res. 20 (1): gmr18752

Received October 14, 2020

Accepted January 08, 2020

Published February 28, 2021

DOI http://dx.doi.org/10.4238/gmr18752

ABSTRACT. Flavonoids are a group of natural polyphenols that are
typically present in many higher plants as secondary metabolites with
low molecular weight. Diosmin (3',5,7-trihydroxy-4'-
methoxyflavone-7-ramnoglucoside) is a naturally occurring flavonoid
found in relatively large quantities in citrus fruits. We examined the
cytotoxic, antiangiogenic and antimicrobial activity of diosmin. The
cytotoxic effect was assessed by the WST-1 test. Cellular DNA
fragmentation was determined by measuring BrdU-labeled DNA
fragments. The mRNA and protein levels were assessed by qRT-PCR
and Western blot. The minimal inhibitory concentrations (MIC) of
diosmin for six Gram-positive and nine Gram-negative bacteria were
determined by using a microdilution method. Diosmin significantly
and selectively inhibited proliferation depending on concentration
and exposure time. Following diosmin treatment of MDA-MB-231
cells, a concentration-dependent and time-dependent increase in the
number of apoptotic BrdU-labeled DNA fragments was observed.
Exposure of MDA-MB-231 breast cancer cells to diosmin for $24 \mathrm{~h}$
markedly increased the mRNA expression of Bax and caspase-3,
whereas the expressions of Bcl-2 and Bcl-XL were decreased.
Furthermore, Western blotting demonstrated that protein expression 
of Bcl-2 and Bcl-XL was downregulated, while the expression of Bax and caspase-3 proteins was upregulated. Based on the MICs, significant activity was only seen against Gram-positive bacteria. We conclude that diosmin is a potential candidate for use in the treatment of breast cancer and for controlling infection.

Key words: Antibacterial; Apoptotic; Cytotoxic; Diosmin; Flavanoids; Cancer

\section{INTRODUCTION}

Breast cancer is the most commonly diagnosed tumor type and the second deadliest form of cancer among women (Jemal et al., 2011). Triple-negative breast cancers (TNBCs) representing approximately $15 \%$ of all breast cancer cases, do not express human epidermal growth factor receptors (HER2), estrogen receptors (ER) or progesterone receptors (PR); they are more likely to metastasize than others. As many of the current clinical treatments for breast cancer, such as antiestrogens, aromatase inhibitors or herceptin, target these receptors, TNBCs are harder to treat with currently available therapies. MDA-MB-231 cells, known to be resistant to a large number of anti-cancer agents are aggressive and invasive TNBC cells (Zordoky et al., 2014). Although advances in treatment have significantly reduced the risk of both recurrence and death from breast cancer, mortality from cancer recurrence with acquired resistance, metastatic or not, remains a challenge in the scientific and clinical settings (Kim et al., 2010). Alternative natural chemotherapy agents are expected to enhance treatment efficacy by minimizing the toxicity to noncancerous tissue and the adverse effects. Treatment success may be partly enhanced by the development of new drugs with enhanced specificity for the tumor and a higher efficacy.

Plant-derived natural products stand out as promising, potent novel chemotherapeutic agent candidates for cancer therapy thanks to their lower cost and fewer side effects. Among such phytochemicals, flavonoids have received significant attention for the wide range of their biochemical and pharmacological properties (Androutsopoulos et al., 2010). Flavonoids are a group of natural polyphenols that are typically present in many higher plants as secondary metabolites with low molecular weight (Rehman et al., 2013). Diosmin (3',5,7-trihydroxy-4'-methoxyflavone-7-ramnoglucoside) is a naturally occurring flavonoid found in relatively large quantity in citrus fruits (Tahir et al., 2013). A biologically very active flavonoid, diosmin has shown antioxidant (Cotelle et al., 1996), anti-inflammatory (Crespo et al., 1999), antidiabetic (Mannuel et al., 1999), antihyperglycemic (Smith et al., 1999), anti-lipid peroxidative (Berqvist et al., 1981), antimutagenic (Camarda et al., 2007), antihypertensive (Silambarasan and Raja 2012), antihyperlipidemic (Marchard et al., 2000), anti-arteriosclerotic, anti-apoptotic (Rehman et al., 2013) as well as antitumor activity (Srinivasan and Pari, 2012). It was also found to reduce significantly the incidence and multiplicity of esophageal cancer (Tanaka et al., 1997) and provide protection against $\mathrm{N}$-methyl $\mathrm{N}$-amylnitrosamine-induced esophageal tumorigenesis, azoxymethane-induced rat colon carcinogenesis and 4-nitroquinoline 1oxide-induced oral carcinogenesis (Rehman et al., 2013). Based on these biological properties, we decided to examine the antimicrobial activity of diosmin and its cytotoxic, antiapoptotic and antiangiogenic effects on MDA-MB-231 breast cancer cells, in vitro. 


\section{MATERIAL AND METHODS}

\section{Cell culture and treatments}

The human breast cancer cell line MDA-MB-231 (ER-) (HTB-26, ATCC) and human embryonic kidney cell line 293T (CRL-3216, ATCC) were obtained from the American Type Culture Collection. The cells were grown in RPMI-1640 medium supplemented with $10 \%$ fetal bovine serum, $0.1 \mathrm{mM}$ non-essential amino acids, $5 \%$ sodium pyruvate, $2 \mathrm{mM} \mathrm{L}$-glutamine and $10 \mu \mathrm{g} / \mathrm{mL}$ gentamicin in humidified atmosphere of $5 \%$ $\mathrm{CO}_{2}, 95 \%$ air at $37^{\circ} \mathrm{C}$. They were passaged, with medium changes, every 3-4 days. In cell viability experiments, the cells were seeded in 96-well plates and grown to a confluence of $75-85 \%$. Cells were treated in the following groups: control (no treatment), vehicle $(0.1 \%$ DMSO) and diosmin (0.01-1,000 $\mu \mathrm{g} / \mathrm{mL}$ ). Diosmin (D3525, CAS-520-27-4) was purchased from the Sigma Chemical Company (St. Louis, MO, USA). Antibodies against Bcl 2, Bcl$\mathrm{X}_{\mathrm{L}}, \mathrm{Bax}$ and caspase-3 were purchased from Santa Cruz Biotechnology (Santa Cruz, CA). RPMI-1640 medium and fetal bovine serum (FBS) were purchased from Invitrogen Life Technologies Corporation (Carlsbad, CA, USA). Diosmin was dissolved in $0.1 \%$ dimethyl sulfoxide (DMSO), with a final concentration DMSO concentration not to exceed $0.1 \%$ $(\mathrm{v} / \mathrm{v})$. Stock solutions were appropriately diluted in serum-free medium. Cells were incubated with $0.01,0.1,1,5,10,25,50,75,100,150,200,500$ and $1000 \mu \mathrm{g} / \mathrm{mL}$ of diosmin for 24,48 or $72 \mathrm{~h}$.

\section{Bacterial strains}

The following reference strains were used in the study: for Gram-positive bacteria, Staphylococcus aureus ATCC 25923 ( $\beta$-lactamase-negative), Staphylococcus aureus ATCC 29213 ( $\beta$-lactamase-positive), Staphylococcus aureus ATCC 43300 (Methicillin-resistant (MRSA)), Staphylococcus epidermidis ATCC 12228 (Quality control strain), Enterococcus faecalis ATCC 29212 (Vancomycin-sensitive), Enterococcus faecalis ATCC 51299 (Vancomycin-resistant enterococcus (VRE)); for Gram-negative bacteria, Escherichia coli ATCC 25922 ( $\beta$-lactamase-negative), Escherichia coli ATCC 35218 ( $\beta$-lactamase-positive), Klebsiella pneumoniae ATCC 13883 (Quality control strain), Klebsiella pneumoniae ATCC 700603 (Extended spectrum $\beta$-lactamase (ESBL) positive), Enterobacter cloacae ATCC 23355 (Cefalosporinase-positive), Serratia marcescens ATCC 8100 (Quality control strain), Proteus vulgaris ATCC 13315 (Quality control strain), Salmonella typhimurium ATCC 14028 (Quality control strain), Pseudomonas aeruginosa ATCC 27853 (Quality control strain). Before testing, the bacterial strains were cultured overnight at $37^{\circ} \mathrm{C}$ in blood agar (Merck KGaA, Darmstadt, Germany) and checked for purity.

\section{Cell viability assay}

MDA-MB-231 and $293 \mathrm{~T}$ cells were seeded in 96 microtiter plates at a density of $5 \times 10^{3}$ cells/well in $200 \mu \mathrm{L}$ medium and incubated overnight to allow cell attachment before diosmin treatment. Cytotoxicity was measured by the tetrazolium salt WST-1 colorimetric assay, performed as recommended by the manufacturer (Catalog\#: 11.644.807.001, Roche Diagnostics GmbH, Mannheim, Germany). After 24, 48 and $72 \mathrm{~h}$ exposure, $10 \mu \mathrm{L}$ of the 
WST-1 reagent was added to each well and the plates were incubated $4 \mathrm{~h}$ longer at $37^{\circ} \mathrm{C}$, the absorbances were monitored at $450 \mathrm{~nm}$ using an ELISA microplate reader (Thermo Labsystem Multiscan Spectrum, Thermolabsystem, Chantilly, VA, USA). The growth inhibitory effect of diosmin, stated as the inhibition of cell proliferation, was calculated by using the following formula (Shang et al., 2009): \% Cytotoxicity $=(1-($ OD450 treated/OD450 control) x 100). Assays were performed in quadruplicate in four independent experiments. Changes in cell morphology were visualized on an Olympus IX71 inverted microscope. The $50 \%$ cytotoxic and inhibitory concentrations $\left(\mathrm{CC}_{50}\right.$ and $\left.\mathrm{IC}_{50}\right)$ were the concentrations at which 50\% cytotoxicity was achieved in $293 \mathrm{~T}$ and MDA-MB-231 cells, respectively; they were derived by a nonlinear regression model (curve fit) based on a sigmoidal dose-response curve (variable slope) and computed using Graph-Pad Prism, version 4.00 (Graph-Pad Software, San Diego, CA). The selectivity index (SI) as ratio of $\mathrm{CC}_{50}$ (cytotoxicity to 293T) to $\mathrm{IC}_{50}$ (cytotoxicity to MDA-MB-231), was also calculated (Hafidh et al., 2013).

\section{Determination of colony formation}

MDA-MB-231 and $293 \mathrm{~T}$ cells (500 cells/well) were assayed in 24-well plates for colony-forming ability when exposed to diosmin $(0.01-1,000 \mu \mathrm{g} / \mathrm{mL})$ or vehicle $(0.1 \%$ DMSO) for 24,48 or $72 \mathrm{~h}$. The cells were allowed to grow and form colonies for 10 days. The colonies were then fixed in a solution of methanol and acetic acid (3:1), stained with $0.05 \%$ crystal violet and counted using a hemocytometer. Four replicate experiments were performed for each cell line. Clonogenicity was evaluated by counting colonies containing 50 or more cells. Results were expressed as percentage of control cell colonies. The inhibition rate of diosmin against MDA-MB-231 and $293 \mathrm{~T}$ cell colony formation was calculated by the following formula (Zhang et al., 2014): Inhibition of Colony Formation $(\%)=($ colony number of (control cells-treated cells) / colony number of control cells) x 100.

\section{Quantitative real-time PCR}

Total RNA from both diosmin-treated and untreated MDA-MB-231 cells was isolated using the RNeasy mini kit (Qiagen, Germany) according to the manufacturer's instructions. RNA concentrations were determined by UV spectroscopy. Synthesis of cDNA was performed with $50 \mathrm{ng}$ of total RNA in a final volume of $20 \mu \mathrm{L}$, using Sensiscript Reverse Transcriptase (Qiagen, Germany) with $2 \mu \mathrm{M}$ oligo (dT) 16 and following the manufacturer's protocol. The mRNA levels of Bcl-2, Bcl-xL, Bax and caspase-3, as well as beta-actin, the reference gene, were assayed using SYBR Green-based real-time PCR. All PCR were performed using the LightCycler ${ }^{\circledR} 2.0$ real-time PCR system (Roche Diagnostics $\mathrm{GmbH}$, Mannheim, Germany); data was analyzed by the Livak method (Livak and Schmittgen 2001). SYBR-Green real-time PCR was performed using $50 \mathrm{ng}$ of cDNA template in a $20 \mu \mathrm{L}$ reaction mixture containing $0.50 \mu \mathrm{M}$ of each primer and $10 \mu \mathrm{L}$ SYBRGreen real-time PCR Master Mix (Qiagen, Germany). The PCR reaction was run as follows: $95^{\circ} \mathrm{C}$ for $10 \mathrm{~min}, 40$ cycles at $95^{\circ} \mathrm{C}$ for $30 \mathrm{~s}, 52^{\circ} \mathrm{C}$ for $20 \mathrm{~s}$ and $72^{\circ} \mathrm{C}$ for $60 \mathrm{~s}$. The quantitative real-time PCR data was analyzed by a comparative threshold $(\mathrm{Ct})$ method and the fold inductions of samples were compared with the untreated samples. Beta-actin was 
used as an internal reference gene to normalize the expression of Bcl-2, Bcl-xL, Bax and Caspase-3. The $\mathrm{Ct}$ cycle was used to determine the expression level of selected genes in the controls and the diosmin-treated MDA-MB-231 cells. The gene expression level was then calculated as described (Yuan et al., 2006). The results were expressed as the ratio of reference gene to target gene by using the following formula: $\Delta \mathrm{Ct}=\mathrm{Ct}$ (selected genes) - $\mathrm{Ct}$ (b-actin). To determine the relative expression levels, the following formula was used: $\Delta \Delta \mathrm{Ct}=\Delta \mathrm{Ct}$ (Treated) - $\Delta \mathrm{Ct}$ (control). The expression levels were thus expressed as $\mathrm{n}$-fold differences relative to the calibrator. The value was used to plot the expression of selected genes using the expression $2^{-\Delta \Delta \mathrm{Ct}}$. The ratio of Bax to Bcl-2 determines the susceptibility of cells to undergo apoptosis; therefore the $\mathrm{Bax} / \mathrm{Bcl}-2$ ratio was calculated using the following equation (Hafidh et al., 2013): $(\mathrm{Bax} / \mathrm{Bcl}-2)$ ratio $=($ mean PCR efficiency for Bax and Bcl$2) \mathrm{x}\left(\mathrm{Ct}_{\mathrm{Bcl} 2}-\mathrm{Ct}_{\mathrm{Bax}}\right)$. The primer sequences used were as follows: for Bcl-2 (NM_000633) the forward primer 5'- CATGCTGGGGCCGTACAG-3' and the reverse primer 5'CATGCTGGGGCCGTACAG-3'; for Bcl-xL (NM_138578) the forward primer 5'TGCATTGTTCCCATAGAGTTCCA-3' and the reverse primer 5'CCTGAATGACCACCTAGAGC-3'; for Bax (NM_138761) the forward primer 5'AGCTGCAGAGGATGATTGCC-3' and the reverse primer 5'GAAGTTGCCGTCAGAAAACATG-3'; for caspase-3 (NM_032991) the forward primer 5'-TGGCACAAAGCGACTGGAT-3' and the reverse primer 5'GTGGAGGCCGACTTCTTG-3'; for beta-actin (NM_001101) the forward primer 5'TTCTACAATGAGCTGCGTGTG-3' and the reverse primer 5'CTGGGGTGTTGAAGGTCTCAAA-3' (Olenyuk et al., 2004).

\section{Caspase colorimetric protease assay}

Caspases-3 activity was determined using the commercial ApoTarget Colorimetric Protease Assay Sampler Kit, purchased from Invitrogen Company (Catalog\# KHZ1001, USA) according to the manufacturer's protocol. In brief, after 24,48 or $72 \mathrm{~h}$ diosmin treatment, cells $\left(5 \times 10^{6}\right.$ cells/ 6-well plate) were collected, washed twice in PBS and lysed in $100 \mu \mathrm{L}$ chilled cell lysis buffer on ice for $15 \mathrm{~min}$. After centrifugation $(10,000 \mathrm{xg})$ the cytosol extracts were transferred to different Eppendorf tubes; the protein concentration of the samples was assayed by a Bio-Rad protein assay kit (Bio-Rad Laboratories, Hercules, CA) and measured against bovine serum albumin standards. Cytosol extracts were seeded into a standard 96-well plate containing $20 \mu \mathrm{g}$ protein per well. Samples were mixed with $10 \mu \mathrm{L}$ of caspase-3 substrate (DEVD-pNA) and incubated at $37^{\circ} \mathrm{C}$ for $2 \mathrm{~h}$, protected from direct light. The released pNA levels were measured at $405 \mathrm{~nm}$ wavelength with an ELISA plate reader (Thermo Labsystem Multiscan Spectrum, Thermolabsystem, Chantilly, VA, USA). Background absorbances determined from wells containing culture medium without cells were subtracted from the absorbance of both treated and untreated samples before calculating fold change in caspase activity. The fold increase in caspase activity was determined by direct comparison to the level of untreated controls (Nikhil et al., 2014).

\section{Western blot analysis}

To determine the effects of diosmin on Bcl-2, Bcl- $\mathrm{X}_{\mathrm{L}}$, Bax and caspase-3 protein levels, cell homogenates were studied by standard western blot techniques. After the 
incubation period, cells were washed with ice-cold PBS. One $\mathrm{mL}$ ice-cold RIPA (Radio Immunoprecipitation Assay buffer) lysis buffer was added per $100 \mathrm{~mm}$ cell culture dish placed on ice. Adhering cells were scraped off using a cold plastic cell scraper. The cell suspension was immediately transferred into a pre-cooled microfuge tube and centrifuged at $2000 \mathrm{xg}$ for $10 \mathrm{~min}$. Samples were then sonicated on ice in the presence of protease inhibitors (Papi et al., 2013). The supernatant was aspirated and placed in a new fresh tube kept on ice. The protein concentration in the samples was assayed using a Bio-Rad protein assay kit (Bio-Rad Laboratories, Hercules, CA) and measured against bovine serum albumin standards. Proteins $(50 \mu \mathrm{g})$ from the cell homogenate were size-fractioned in a $10 \%$ acrylamide gel by SDS-PAGE and then transferred to polyvinylidene difluoride membranes (Hybond-P, Amersham Pharmacia Biotech, Piscataway, NJ) with a semidry transfer apparatus. The membranes were blocked with TBS-5\% milk, then probed with anti-caspase3, anti-Bcl-2, anti- Bcl- $\mathrm{X}_{\mathrm{L}}$ and anti-Bax (sc-65496, sc-130307, sc7195 and sc 493, respectively, Santa Cruz Biotechnology, Santa Cruz, CA). The primary antibodies were diluted 1:100 in TBS-5\% milk and the goat anti-human IgG-HRP (sc-2453) was diluted 1:1000. The membranes were washed and blots were developed using an enhanced chemoluminescence Western blotting detection kit (ECL Plus kit, Amersham Biosciences RPN2132, USA) and exposed to X-ray film (Sigma C4729-1EA, Sigma Z363006-50) for 230 s. Molecular weight standards (sc-2035, Santa Cruz Biotechnology, Santa Cruz, CA) were used to determine molecular weights of the visualized bands. Protein loading was controlled by Glyceraldehyde 3-phosphate dehydrogenase (GAPDH), 1:1000 (sc-365062, Santa Cruz Biotechnology, Santa Cruz, CA) as an internal control.

\section{Cellular DNA fragmentation ELISA}

The potential of diosmin to induce DNA fragmentation in MDA-MB-231 cells was studied using a cellular DNA fragmentation ELISA kit (\# 11585045 001, Roche Diagnostics) as per the manufacturer's instructions. Briefly, $5 \times 10^{5} / \mathrm{mL}$ MDA-MB-231 cells were labeled with $10 \mu \mathrm{M} \mathrm{BrdU}$ and incubated for $4 \mathrm{~h}$ at $37^{\circ} \mathrm{C}$. The cells were centrifugated at $750 \mathrm{xg}$ for 10 minutes. The BrdU-containing supernatant was then carefully and thoroughly removed; the cells were resuspended in BrdU-free RPMI. Flatbottom microtiter plates (MTP) were seeded with $100 \mu \mathrm{L}$ of BrdU-labeled MDA-MB-231 $\left(1 \times 10^{5}\right.$ cells $\left./ \mathrm{mL}\right)$, treated with diosmin $\left(1 / 4 \mathrm{IC}_{50}, 1 / 2 \mathrm{IC}_{50}, \mathrm{IC}_{50}, 2 \times \mathrm{IC}_{50}, 4 \times \mathrm{IC}_{50}\right)$ for $6 \mathrm{~h}$. After the incubation period, the supernatant culture medium was removed and $200 \mu \mathrm{L}$ of $1 \mathrm{x}$ incubation solution was added to each well. The plates were then incubated at room temperature for $30 \mathrm{~min}$ to lyse the cells, which were then centrifugated at $1,000 \mathrm{x} \mathrm{g}$ for 10 minutes. The supernatants were transferred to fresh eppendorfs and in order to obtain the DNA fragments from cytoplasm, $200 \mu \mathrm{L} 1 \mathrm{x}$ incubation solution provided in the kit was added to supernatants to lyse the cells and incubated for $30 \mathrm{~min}$ at room temperature. Following the ELISA procedure, after centrifugation $(1,000 \times \mathrm{g}$ for $10 \mathrm{~min}), 100 \mu \mathrm{L}$ of the supernatant was transferred to anti-DNA-coated flat-bottom 96-well MTP microplates that were incubated for $90 \mathrm{~min}$ at room temperature, following which DNA was denatured by nuclease treatment. Anti-BrdU-POD conjugate solution $(100 \mu \mathrm{L} /$ well $)$ was added and the samples were further incubated for $90 \mathrm{~min}$. The plates were washed three times with $1 \mathrm{X}$ wash buffer. Substrate (TMB, $100 \mu \mathrm{L})$ solution was added for blue color development. 
After the addition of $25 \mu \mathrm{L}$ of stop solution, the absorbances were read at $450 \mathrm{~nm}$ (George et al., 2014).

\section{Determining the minimum inhibitory concentration (MIC) and minimum bactericidal concentration (MBC)}

MIC and MBC values of diosmin were determined by the microdilution method, performed in sterile 96-well microplates according to the protocol described by CLSI (2018). Diosmin dissolved in DMSO was diluted with Mueller-Hinton Broth (MHB, Merck KGaA, Darmstadt, Germany) to obtain an initial concentration of $1024 \mu \mathrm{g} / \mathrm{mL}$. Each well was filled with $50 \mu \mathrm{L}$ of cation-adjusted MHB (CAMHB). The compound $(50 \mu \mathrm{L})$ was added into the first well and transferred to the next in order to obtain serial two-fold dilutions which ranged from 0.125 to $256 \mu \mathrm{g} / \mathrm{mL}$. Each strain of bacteria was suspended in $5 \mathrm{~mL}$ of sterile $0.9 \% \mathrm{NaCl}$ solution; the density of the suspensions was adjusted to a 0.5 McFarland turbidity standard ( $1 \times 10^{8}$ Colony Forming Units $(\mathrm{CFU}) / \mathrm{mL}$, BioMérieux, Marcy l'Etoile, France). The wells were inoculated with $50 \mu \mathrm{L}$ of each bacteria $\left(5 \times 10^{5} \mathrm{CFU} / \mathrm{mL}\right)$. The same procedure was applied to determine the antimicrobial activity of standard reference antibiotics. A growth control (medium + microorganisms + DMSO) and a control for sterility (MHB only) were added. The microtitration plates were aerobically incubated at $37^{\circ} \mathrm{C}$ for $24 \mathrm{~h}$. Bacterial growth was indicated by the presence of a white "pellet" in the bottom of the wells. The MIC was defined as the lowest antimicrobial agent concentration which inhibited visible growth. Each experiment was performed four times.

To evaluate $\mathrm{MBC}, 10 \mu \mathrm{L}$ from each culture medium with no visible growth was subcultured on blood agar. Plates were then incubated during $24 \mathrm{~h}$ at $37^{\circ} \mathrm{C}$ for fast growing Gram-negative bacilli, $48 \mathrm{~h}$ for staphylococci and enterococci, and $72 \mathrm{~h}$ for all other bacteria. MBC was defined as the lowest concentration of the antimicrobial agent which could kill $99,9 \%$ of microorganisms.

\section{Statistical analysis}

All measurements were expressed as their mean \pm 1 SEM. Data were analyzed using one-way ANOVA followed by Dunnett's Multiple Comparisons Test for comparison of group means to control, or by Student's two-sample t-test (Graph Pad InStat., USA). A pvalue of $<0.05$ was considered statistically significant. Different alphabetical superscripts in the tables indicate statistically significant differences between different samples. Best fit graphs were generated using SigmaPlot 10.0 (Systat Software, San Jose, CA) and CorelDRAW X5 (Corel Corporation).

\section{RESULTS AND DISCUSSION}

To examine the cytotoxic potential of diosmin, we incubated both MDA-MB-231 and 293-T cells with varying concentrations of diosmin $(0.01$ and $1000 \mu \mathrm{g} / \mathrm{mL})$ for 24,48 or $72 \mathrm{~h}$ and then performed the WST-1 assay, which indirectly indicates metabolically active cells in vitro (Table 1). As shown in Figure 1a, diosmin induced a significant inhibition in MDA-MB-231 cell proliferation in a both dose-dependent and time-dependent manner, with calculated $\mathrm{IC}_{50}$ values of $88.24 \pm 5.03,50.26 \pm 3.97$ and $17.81 \pm 1.67 \mu \mathrm{g} / \mathrm{mL}$ 
at 24,48 and $72 \mathrm{~h}$ respectively. In all subsequent experiments, considering the time period associated, these $\mathrm{IC}_{50}$ values obtained were rounded to their integers; 88,50 and $18 \mu \mathrm{g} / \mathrm{mL}$. Human embryonic kidney cells, 293-T, were used to measure the possible cytotoxicity of diosmin on normal tissue cells. While diosmin had a strong antiproliferative activity on MDA-MB-231 cells, no inhibitory effect was seen in 293-T cells. The $\mathrm{CC}_{50}$ values of diosmin on $293 \mathrm{~T}$ cells $(763.01 \pm 10.87,628.59 \pm 8.36$ and $519.20 \pm 6.53 \mu \mathrm{g} / \mathrm{mL}$ at 24,48 and $72 \mathrm{~h}$, respectively) showed a significant difference between the cytotoxic effect of diosmin in 293-T cells and that in MDA-MB-231 cells $(\mathrm{P}<0.001)$ (Figure 1b). Also, no effect on cell viability could be detected for DMSO $(0.1 \% \mathrm{v} / \mathrm{v})$, used as a solvent for diosmin $(\mathrm{p}>0.05)$. To compare the cytotoxic activity of diosmin on normal tissue cells and cancer cells, we calculated the selectivity index (SI), a ratio of the highest concentration causing $50 \%$ death in normal cells $\left(\mathrm{CC}_{50}\right)$ to the lowest concentration that causes $50 \%$ death in cancerous cells $\left(\mathrm{IC}_{50}\right)$ (Hafidh et al., 2013). The SI value of diosmin on MDA-MB-231 cells was $42.73 \pm 8.23$. This remarkable cytotoxicity in MDA-MB-231 cells, coupled with an absence of toxicity to normal tissue cells, suggests that diosmin may be safe and selective as an anticancer agent.

Table 1. Cytotoxic activity of diosmin on $293 \mathrm{~T}$ and MDA-MB-231 cells according to WST-1 cell viability assay.

\begin{tabular}{lcrr}
\hline & $\mathbf{2 4} \mathbf{h}$ & $\mathbf{4 8} \mathbf{h}$ & \multicolumn{1}{c}{$\mathbf{~ h}$} \\
\hline $\mathrm{IC}_{50}$ & $88.24 \pm 5.03$ & $50.26 \pm 3.97$ & $17.81 \pm 1.67$ \\
$\mathrm{CC}_{50}$ & $763.01 \pm 10.37$ & $628.59 \pm 8.36$ & $519.20 \pm 6.53$ \\
\hline
\end{tabular}

(a)

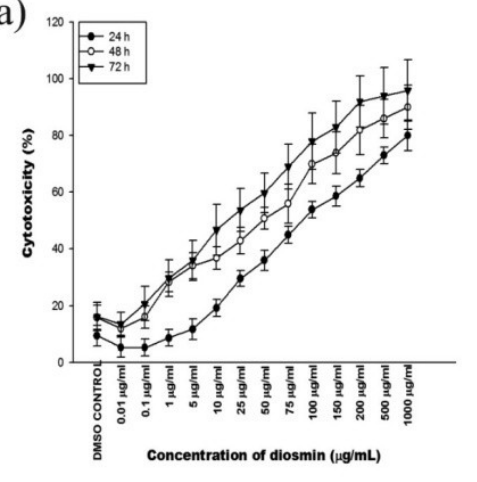

(b)

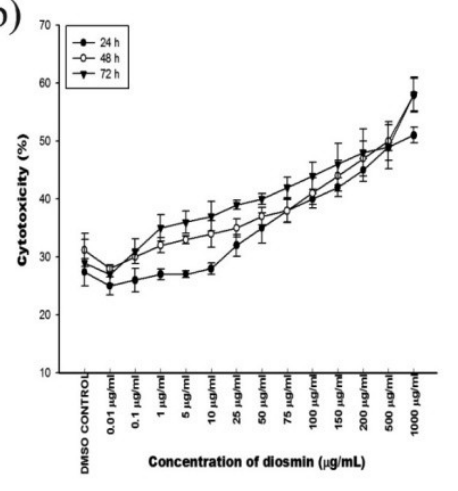

Figure 1. Cytotoxic potential of diosmin on MDA-MB-231 (a) and 293-T (b) cells in various concentrations $(0.01$ and $1000 \mu \mathrm{g} / \mathrm{mL})$ for 24,48 and $72 \mathrm{~h}$ was assessed by WST-1 assay. Error bars represent standard error of mean of four independent experiments.

The shape of diosmin-treated and untreated cells was observed under an inverted microscope. Untreated MDA-MB-231 cells exhibited regular shapes (Figure 2), while treated cells revealed morphological alterations such as loss of contact with neighboring cells, more elongated shapes and rounding induced by diosmin. The loss in cell contact induced by diosmin resulted in scattered clusters of MDA-MB-231 cells. Especially MDA- 
MB-231 cells treated with diosmin at $\mathrm{IC}_{50}$ exhibited obvious morphological changes, characterized by the loss of epithelial morphology and fibroblast-like, appearance with filopodia-like extensions when compared to the untreated cells. Up to $72 \mathrm{~h}$ of exposure, the treated cells appeared smaller and rounded, indicating characteristic apoptotic cell properties. Diosmin exposure was not associated with further change in cell morphology past $72 \mathrm{~h}$ of exposure.

To support WST-1 cell viability experiment results, MDA-MB-231 cells were assayed for colony-forming ability; the inhibition rate of diosmin against colony formation was calculated. Untreated control cells provided $278 \pm 20.8$ colonies while the colony numbers of diosmin-treated $(1 / 4)$ cells were $235 \pm 12.17(\mathrm{P}>0.05), 185 \pm 11.51(\mathrm{P}<0.01)$, $73.4 \pm 7.06(\mathrm{P}<0.001), 31 \pm 4.39(\mathrm{P}<.001)$ and $20.4 \pm 1.96(\mathrm{P}<0.001)$, for exposure to concentrations of $1 / 4 \mathrm{IC}_{50}, 1 / 2 \mathrm{IC}_{50}, \mathrm{IC}_{50}, 2 \mathrm{x} \mathrm{IC} \mathrm{I}_{50}$ and $4 \mathrm{x} \mathrm{IC} 50$, respectively (Figure $3 \mathrm{a}$ ).

The activation of caspase- 3 was evaluated to determine whether diosmin induced apoptosis in MDA-MB-231 cells. As shown in Figure 3b, diosmin at $\mathrm{IC}_{50}$ provided 1.23, 5.42 and 8.03 -fold increases in caspase- 3 activity compared with non-treated cells at the end of 24,48 and $72 \mathrm{~h}$, respectively, suggesting that diosmin time-dependently induced apoptotic response in MDA-MB-231 cells, possibly through a cascade-dependent pathway. The activity of caspase- 3 increased in direct proportion to the number of cells undergoing apoptosis and the observed increase in caspase- 3 activity was only significant up to $72 \mathrm{~h}$ of incubation. The slowed activity of caspase- 3 after $72 \mathrm{~h}$ is presumably due to the activation of other apoptosis-related cascades which lead the accumulation of dead cell debris interfering with the enzyme action.

In the cellular DNA fragmentation assay, after treatment of MDA-MB-231 cells with diosmin, BrdU-labeled DNA fragments were quantified at $450 \mathrm{~nm}$. A concentrationdependent and time-dependent increase in the number of apoptotic DNA fragments was observed in cells, detected by an increase in absorbance. (Figure 3c).

To determine the effect of diosmin on Bcl-2, Bcl- $\mathrm{X}_{\mathrm{L}}$, Bax and caspase-3 protein levels, cellular lysates were prepared and studied by standard western blot techniques using specific antibodies and GAPDH as an internal control. The expression level of the Bcl-2, Bcl- $\mathrm{X}_{\mathrm{L}}$, Bax and caspase- 3 proteins in controls and diosmin-treated MDA-MB-231 cells are shown in Figure 3d. When compared to GAPDH, exposure of MDA-MB-231 cells to diosmin for $72 \mathrm{~h}$ markedly increased the protein expression of Bax and caspase-3, whereas the expression of Bcl-2 was concomitantly decreased. On the other hand, even though change in the expression of Bcl- $\mathrm{X}_{\mathrm{L}}$ was not as significant as for Bcl-2 protein, the diminished expression can also be observed. As can be seen from the thickness of the visualized bands of Bax and $\mathrm{Bcl}-2$ proteins, the $\mathrm{Bax} / \mathrm{Bcl}-2$ ratio was significantly increased.

In the quantitative real-time PCR analysis to determine the effect of diosmin on selected pro-apoptotic and anti-apoptotic genes, the PCR efficiency of the primers used was greater than $90 \%$ and the correlation coefficients greater than 0.99 . As can be seen from Figure $4 \mathrm{a}$, treatment with diosmin at $\mathrm{IC}_{50}$ for 24,48 or $72 \mathrm{~h}$ significantly upregulated Bax (P $<0.05)$ and caspase- 3 expression $(\mathrm{P}<0.001)$ and downregulated the expression of apoptotic Bcl-2 $(\mathrm{P}<0.01)$ and Bcl- $\mathrm{X}_{\mathrm{L}}(\mathrm{P}<0.05)$ as well as that of VEGF $(\mathrm{P}<0.05)$ in MDA-MB231 cells. The Bax/Bcl-2 ratio was calculated in treated and untreated MDA-MB-231 cells, which in cells treated with diosmin for 24,48 or $72 \mathrm{~h}$ were, respectively, $1.83 \pm 0.19$ ( $\mathrm{P}<$ $0.05), 3.46 \pm 1.72$ ( $\mathrm{P}<0.001), 6.18 \pm 3.07$ ( $\mathrm{P}<0.001)$, in untreated cells was it amounted to 
$0.47 \pm 0.35$. Our results of real time PCR endorsed western blot analysis and provides evidence that diosmin has crucial potential to induce apoptosis in MDA-MB-231 cells.

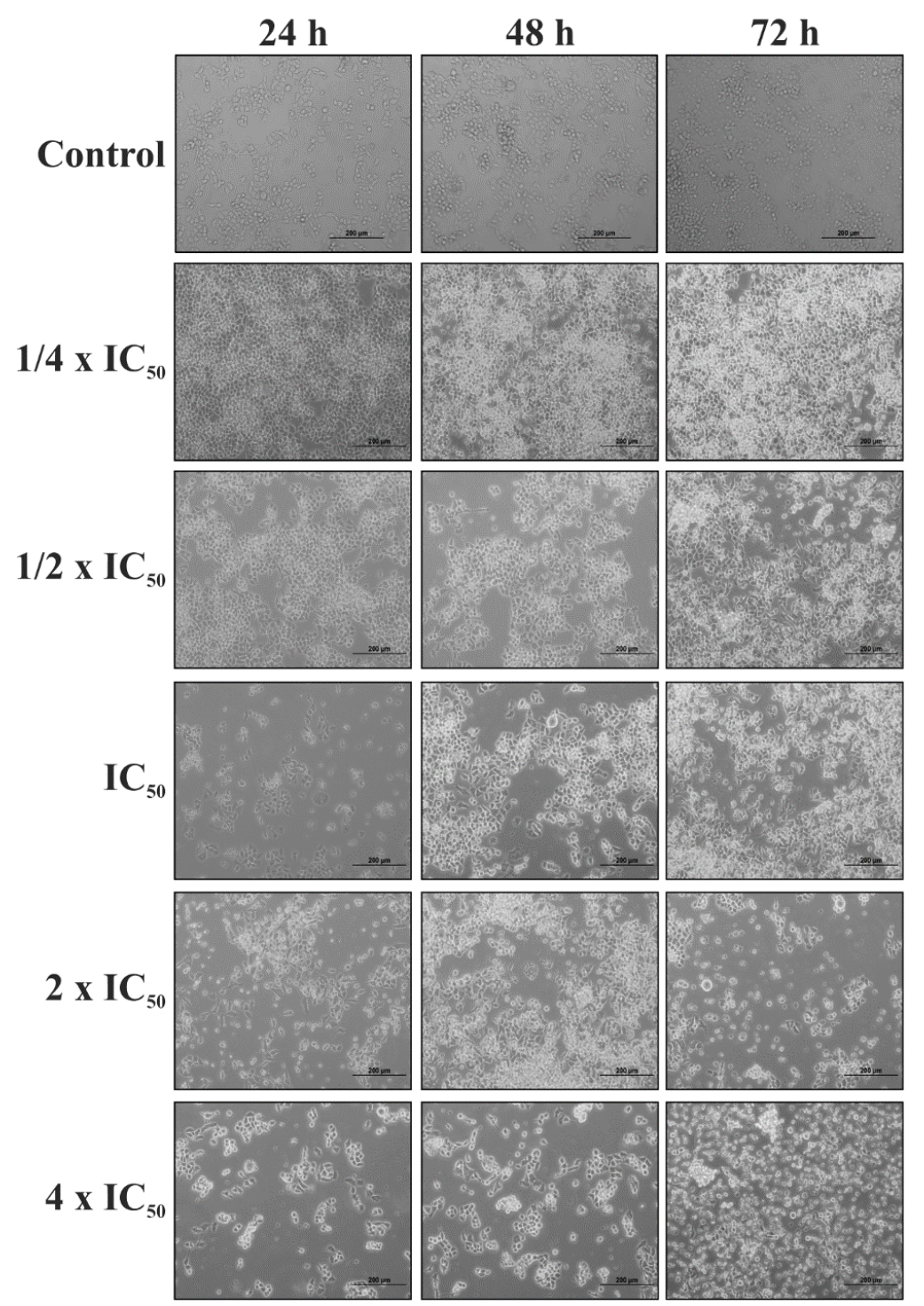

Figure 2. Cell morphologies were visualized under an Olympus IX71 inverted microscope (20x). Typical morphological features of control and diosmin treated MDA-MB-231 cells after 24, 48 and $72 \mathrm{~h}$.

The MIC of diosmin on six Gram-positive and nine Gram-negative bacteria was measured by microdilution. As shown in Table 2, diosmin had both inhibitory and bactericidal activity against the Gram-positive bacteria. Of note, the MIC and MBC values of diosmin were not different. The lowest MIC and MBC was determined against $S$. aureus 
ATCC $25923(64 \mu \mathrm{g} / \mathrm{mL})$. The activity against S. aureus ATCC 29213 and 43300, S. epidermidis ATCC 12228, E. faecalis ATCC 29212 and 51299 was in the $128-256 \mu \mathrm{g} / \mathrm{mL}$ range. No inhibitory activity was observed for any of the Gram-negative bacteria tested.

Table 2. Minimum in inhibitory concentration (MIC) and minimum bactericidal concentration (MBC) values of diosmin and antibiotics against the bacterial strains.

\begin{tabular}{|c|c|c|c|c|c|}
\hline \multirow[b]{2}{*}{ Bacteria species } & \multicolumn{2}{|l|}{ MIC } & \multicolumn{3}{|c|}{ MBC } \\
\hline & $D(\mathrm{mg} / \mathrm{ml})$ & $\mathrm{A}(\mathrm{mg} / \mathrm{ml})$ & $\mathbf{N}$ & $\mathrm{D}(\mathrm{mg} / \mathrm{ml})$ & A $(\mathrm{mg} / \mathrm{ml})$ \\
\hline S. aureus ATCC 25923 & 64 & $<0.0625(\mathrm{P})^{\mathrm{a}}$ & - & 64 & 16 \\
\hline S. aureus ATCC 29213 & 128 & $0.5(\mathrm{P})$ & - & 128 & 0.5 \\
\hline S. aureus ATCC 43300 & 128 & $64(\mathrm{OX})^{\mathrm{b}}$ & - & 128 & 128 \\
\hline $\begin{array}{l}\text { S. epidermidis ATCC } \\
12228\end{array}$ & 256 & $1(\mathrm{VA})^{\mathrm{c}}$ & - & 256 & 2 \\
\hline E. faecalis ATCC 51299 & 256 & 32 (VA) & - & 256 & $>128$ \\
\hline E. faecalis ATCC 29212 & 256 & $4(\mathrm{VA})$ & - & 256 & $>128$ \\
\hline $\begin{array}{l}\text { K. pneumoniae ATCC } \\
13883\end{array}$ & $>256$ & $0.5(\mathrm{CAZ})^{\mathrm{d}}$ & - & $>256$ & 0.5 \\
\hline $\begin{array}{l}\text { K. pneumoniae ATCC } \\
700603\end{array}$ & $>256$ & 64 (CAZ) & - & $>256$ & 128 \\
\hline E. coli ATCC 35218 & $>256$ & $8(\mathrm{AMC})^{\mathrm{e}}$ & - & $>256$ & 8 \\
\hline E. coli ATCC 25922 & $>256$ & $4(\mathrm{AMC})$ & - & $>256$ & 8 \\
\hline E. cloacae ATCC 23355 & $>256$ & $<0.0625(\mathrm{MEM})^{\mathrm{f}}$ & - & $>256$ & $<0.0625$ \\
\hline $\begin{array}{l}\text { S. marcescens ATCC } \\
8100\end{array}$ & $>256$ & $<0.0625$ (MEM) & - & $>256$ & $<0.0625$ \\
\hline P. vulgaris ATCC 13315 & $>256$ & $<0.0625(\mathrm{FEP})^{\mathrm{g}}$ & - & $>256$ & $<0.0625$ \\
\hline $\begin{array}{l}\text { P. aeruginosa ATCC } \\
27853\end{array}$ & $>256$ & 0.5 (MEM) & - & $>256$ & 0.5 \\
\hline $\begin{array}{l}\text { S. typhimurium ATCC } \\
14028\end{array}$ & $>256$ & $2(\mathrm{AMP})^{\mathrm{h}}$ & - & $>256$ & 2 \\
\hline
\end{tabular}

Advances in treatment notwithstanding, breast cancer remains a threat to women worldwide. Effective agents continue to be required. A human breast cancer cell line reported as being highly metastatic and aggressive (Li et al., 2008), MDA-MB-231, was chosen as an in vitro model. Naturally occurring phytochemicals have been the object of attention in recent years, as some specifically target apoptotic pathways in cancer cells and provide a new chemotherapy template, sometimes with ethnopharmacological implications. Plant-derived flavonoids are well known for their various anti-inflammatory, anti-allergic, anti-angiogenic, anti-mutagenic and antitumoral activities (Ravishankar et al., 2013).

Diosmin, a bioflavonoid belonging to the flavonoid glycosides, possesses antiinflammatory, antioxidant and anti-mutagenic properties (Tahir et al., 2013). Chemoprevention and antiproliferative effects have been reported in several animal models and human cancer cells. While a few reports suggest an antitumoral effect of diosmin, an anti-proliferative activity of diosmin in MDA-MB-231 breast cancer cells has not been reported to date. This study was designed to study the cytotoxic and antiangiogenic activity of diosmin in breast cancer cells and to evaluate possible antibacterial effects of this compound. Anticancer efficiency of any tested compound depends on its ability to exert maximum effect on cancer cell growth and/ or proliferation while having minimal adverse effects on normal cells. The selective cytotoxic effect of diosmin on MDA-MB-231 were studied here, being the primary screening endpoint for anticancer activity, and compared to 
the effect on the non-tumor $293 \mathrm{~T}$ cells. Diosmin selectively and significantly $(\mathrm{p}<0.001)$ suppressed MDA-MB-231 cell proliferation in vitro compared to non-tumor $293 \mathrm{~T}$ cells at identical concentrations. This study showed diosmin-mediated selective in vitro cell kill of MDA-MB-231 cells for the first time. Such selectivity may indicate specific targeting of MDA-MB-231 cancer cells, with minor or absent adverse effects in normal cells. To characterize the cytotoxic potential of diosmin, we calculated the selectivity index (SI), a ratio of cytotoxicity to biological activity (Dholokiya and Benzeroual 2003). An $\mathrm{SI} \geq 10$ indicates specific cytotoxicity (Hafidh et al., 2013). The SI of diosmin in MDA-MB-231 cells $(42.73 \pm 8.23)$ exceeds this requirement for the specificity of cytotoxic action of diosmin; it also suggests that this flavonoid may selectively induce apoptosis in MDA-MB231 cells. Colony forming ability was assayed to confirm the observed cytotoxic activity. The colony number was significantly reduced after 10 days of diosmin exposure. A simultaneously observed, significant inhibition of proliferation $(p<0.01)$ indicates that diosmin effectively prevents cell proliferation.

(a)

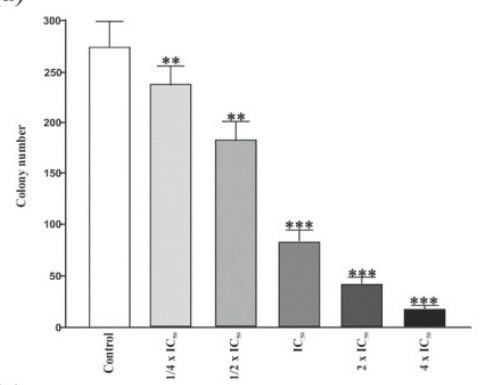

(c)

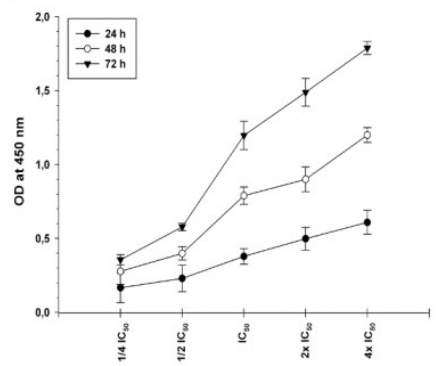

(b)

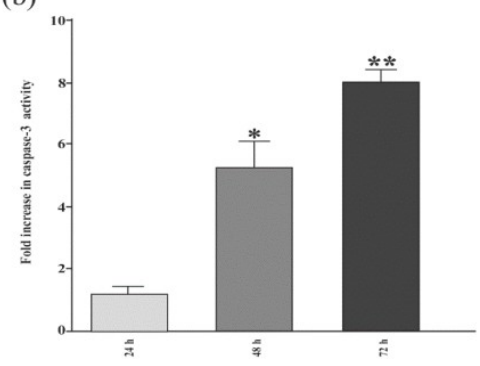

(d)

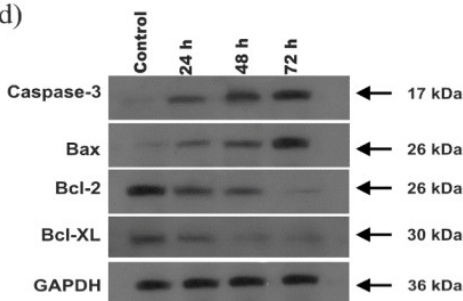

Figure 3. Effect of diosmin on MDA-MB-231 cell colony formation (a). Increase in caspase-3 activity was determined by ELISA for 24, 48 and 72h (b). Apoptosis induction abilities of diosmin in MDA-MB-231 cells was by cellular DNA fragmentation ELISA (c). The effects of diosmin on protein expressions were demonstrated by standard western blot techniques (d). Significant differences are compared with the control, $* \mathrm{P}<0.05$, ** $\mathrm{P}<0.01$ and $* * * \mathrm{P}<0.001$.

Diosmin reportedly inhibits in vitro human hepatocellular carcinoma HA22T cell proliferation (Duny et al., 2012). These authors also examined the effect of diosmin on DNA fragmentation and suggested that diosmin treatment induces in vitro apoptotic cell death in human hepatoma cell lines. In a study investigating the possible protective mechanism of diosmine against cyclophosphamide (CP) -induced liver damage in rats, it was found that proinflammatory cytokines, tumor necrosis factor alpha and interleukin 1 
beta gene expression and protein levels were significantly increased in the liver of rats treated with CP (Germoush et al., 2016). Manthey and Guthrie (2002) reported, however, that diosmin did not exert antiproliferative effect in lung, colon, prostate, melanoma and estrogen receptor positive $(\mathrm{ER}+)$ breast cancer cells in vitro. They studied the effects of diosmin on MCF-7 (ER+) breast cancer cells but did not explore any cytotoxic or antiproliferative effects of this compound against MDA-MB-231 (ER-) cells. Since estrogens and ER play a significant role in breast cancer etiology, different compounds may have different effects according to the ER status of the target cells. At low concentrations $(<10 \mu \mathrm{M})$ genistein, the major isoflavonoid in soybeans, stimulates ER+ breast cancer growth while it may suppress ER- cell growth at any concentration (Yang et al., 2007; Sakumoto et al., 2010). We observed significant cytotoxic effects of diosmin against MDAMB-231 (ER-) cells. The cytotoxic effect of diosmin appears likely, at first glance, to be dependent on the ER status of breast cancer cells. Proliferative and antiproliferative effects of natural prenylated flavones in ER+ and ER- breast cancer cell lines were compared by Pedro et al. in 2006. Prenylated flavones possessing both an isopentenyl group at C-8 and an additional ring linking $\mathrm{C}-3$ and $\mathrm{C}-2$ had a proliferative effect at low concentrations, while at high concentrations all compounds presented an antiproliferative effect, detectable in both $\mathrm{ER}+$ and ER- breast cancer cell lines. In addition, $\mathrm{Li}$ et al. reported that naringin, a major flavonoid extracted from citrus fruit, displayed significant inhibitory effects on the proliferation of TNBC cells; MDA-MB-231, MDA-MB-468 and BT-549, in a dosedependent and time-dependent fashion. These authors also indicated that naringin considerably enhanced caspase- 3 activity in cancer cells, thereby inducing apoptotic cell death ( $\mathrm{Li}$ et al., 2013). The antiproliferative effects of phytoestrogens seems to involve an ER-independent cellular mechanism as reported earlier (Pedro et al., 2003); in this study, we speculate that diosmin may ER-independently induce cell death in MDA-MB-231 cells. In a study with diosmin treated A431 cells, a large number of DNA fragments also appeared from untreated cells. Diosmin downregulated the expression of p53, caspase-3, caspase-9 and $\mathrm{Bcl}-2$, matrix metalloproteinases - 2 and 9 in A431 cells (Buddhan and Manoharan, 2017).

In fact, the sole cytotoxic activity may be unsatisfactory for establishing the antiproliferative effect of a given agent. The cytotoxic activity of any chemotherapy is often concurrent with apoptosis induction in cancer cells (George et al., 2013). Suppression of apoptosis in tumor cells plays an important role in cancer development and progression. Apoptosis induction in tumor cells is accepted therapeutic strategy, particularly for curative treatment (Kumar et al., 2012). In other words, regulation of apoptosis by means of cell growth inhibition and/or cell cycle suppression is pivotal to developing efficient antitumor strategies (Choi et al., 2012). We analyzed the ability of diosmin to induce apoptosis in breast cancer cells by cellular DNA fragmentation ELISA assay, which quantifies the apoptotic DNA fragments present in the cell cytoplasm. Diosmin induced apoptosis at relatively low concentrations $(18 \mu \mathrm{g} / \mathrm{mL})$ in MDA-MB-231. Furthermore, the number of apoptotic fragments in diosmin-treated MDA-MB-231 cells was quantitatively higher compared with that in $293 \mathrm{~T}$ cells. This is evidence that diosmin specifically reacts to ERbreast cancer cells (MDA-MB-231) with a specific mode of apoptotic action. Dosedependent and time-dependent increase in the DNA fragmentation of diosmin-treated MDA-MB-231 cells, determined by the increase in absorbance values, should indicate that diosmin causes apoptosis by inducing DNA damage in this aggressive cell type. Apoptosis 
is generally characterized by morphological changes in apoptotic cells, such as volume reduction, condensation of the nucleus, swelling of the cytoplasm, loss of membrane integrity followed by plasma membrane blebbing, and finally the formation of apoptotic bodies (Choi et al., 2012; George et al., 2012). Morphological change in MDA-MB-231 cells was observed under an inverted microscope after exposure to diosmin at $\mathrm{IC}_{50}$. Typical morphological features of apoptosis were witnessed in diosmin-treated MDA-MB-231 cells, such as detachment from culture plates, rounding of shape, destruction of monolayer, loss of cell-cell contact and formation of apoptotic bodies. Untreated MDA-MB-231 cells exhibit higher confluency, with an original clear appearance. To confirm the cytotoxic and apoptotic effects of diosmin, we studied the probable effects of diosmin on the apoptosisrelated proteins $\mathrm{Bcl}-2, \mathrm{Bax}, \mathrm{Bcl}-\mathrm{X}_{\mathrm{L}}$ and caspase-3. Apoptosis induction can be triggered by both intrinsic (mitochondrial) and extrinsic (death receptor) mechanisms. Caspases, effector proteases, are major components of the apoptotic system; they are divided into three major classes: initiator caspases, effector caspases, and inflammatory caspase in mammals (George et al., 2012). The ultimate protease activated by either intrinsic or extrinsic pathways is caspase-3, which immediately initiates cell death by cleaving many important cellular substrates, playing a key role in the signal transduction cascades of apoptosis. To verify the apoptotic effect of diosmin, we measured caspase- 3 activity by ELISA, western blot and real-time PCR techniques. Diosmin significantly induced both the mRNA and protein levels of caspase-3. A significant increase in caspase-3 activity was obtained in diosmin-treated MDA-MB-231 cells and correspondingly diosmin showed increased protein expression of the $32-\mathrm{kDa}$ caspase-3 protein. It is reported that caspase-3 can cause DNA fragmentation, which eventually leads to cell death (Athar et al., 2009). In this connection, it may be imagined that diosmin treatment stimulated caspase-3 expression, subsequently leading to DNA fragmentation. The results obtained, compatible with this sequence, led us to suggest that diosmin induces MDA-MB-231 cell death through caspase-3 mediated apoptosis.

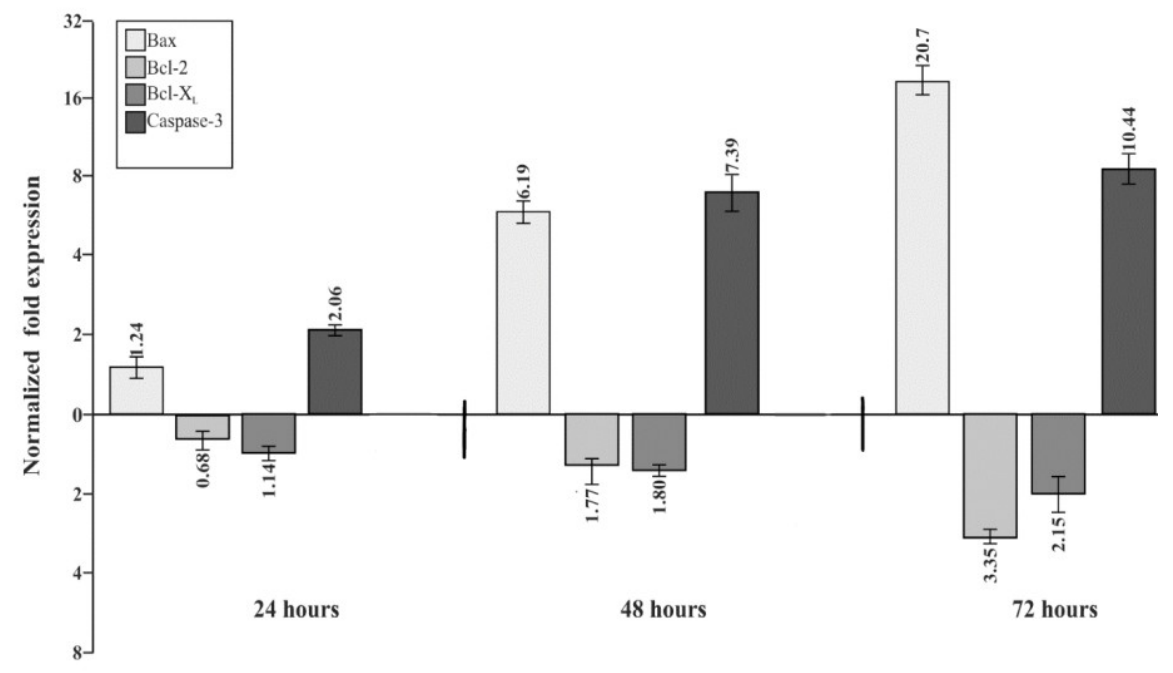

Figure 4: The effects of diosmin on apoptosis-related genes. 
The Bcl-2 family of proteins is at least as important in this context as caspases; they can be classified into two subfamilies of anti-apoptotic and pro-apoptotic molecules. Bcl-2 and Bcl-xL, belonging to the anti-apoptotic proteins of this family, extend cell survival in the presence of several cytotoxic agents and/or anticancer stimuli, whereas the pro-apoptotic Bax and Bak proteins induce apoptosis (Singh et al., 2013). It is well known that the Bax/Bcl-2 ratio and the active Caspase-3 protein level are critical factors in inducing apoptosis (Wang et al., 2014). Given that the ratio of anti-apoptotic vs apoptotic protein is important in determining mitochondria-dependent apoptosis, we calculated the Bax/Bcl-2 protein ratio in diosmin-treated cells. Diosmin significantly increased pro-apoptotic Bax and caspase-3 expression and decreased anti-apoptotic Bcl-2 expression, leading to an upregulation of the Bax/Bcl-2 ratio and slight downregulation of the Bcl-xL levels. Since the expression levels of Bcl-2 and Bax were dramatically changed, we suggest that diosmin may induce the mitochondria-mediated, intrinsic, pathway of apoptosis. This might be one of possible molecular mechanisms through which diosmin induces apoptosis in MDA-MB231 cells.

Infectious disease is the second-leading cause of death worldwide (Butler and Buss 2006; Lam 2007). Resistance to microorganisms develops among both hospitalized and ambulatory patients due to inappropriate or inadequate antibiotic therapy (Ruddock et al., 2011). Therapeutic options to overcome antibiotic resistance in bacteria are currently inadequate. Therefore, it is important to investigate the antimicrobial potential of new compounds, including natural products such as extracts, essential oils and secondary metabolites obtained from various plants (Silva and Fernandes Júnior 2010; Hayek et al., 2013). There are many studies in the literature on the antimicrobial activity of these compounds (Orhan et al., 2010, Wendakoon et al., 2012, Köse et al., 2013). This study examined the antimicrobial activity of the flavonoid compound diosmin on resistant and sensitive bacteria. S. aureus ATCC 25923 ( $\beta$-lactamase negative) was the most sensitive bacteria to diosmin. Diosmin showed mild bactericidal activity against the other Grampositive bacteria tested, while it had none on the Gram-negative bacteria in this study. The different responses of these bacteria against diosmin might be due to structural and compositional differences in cell walls (Sato et al., 2000). The reference antibiotics tested in our study were more effective than diosmin. Diosmin displayed a bactericidal activity equal to that of oxacillin against MRSA. Flavonoids from natural products were shown to possess antimicrobial activity in several studies (Sohn et al., 2004; Celiz et al., 2011; Chan et al., 2013; Sahu et al.; 2016). The synergistic actions of diosmetin and diosmin compounds with different antibiotics against MRSA were investigated by Chan et al. (2013). In this study, five laboratories $S$. aureus strains were used; diosmin alone was ineffective and failed to show any synergism against MRSA. Sahu et al. (2016) studied the antimicrobial activities of silver nanoparticles (AgNPs) synthesized using three different flavonoids (hesperidin, naringin and diosmin) according to disc diffusion method. Antibacterial activity of AgNPs synthesized using diosmin was determined as $6 \mathrm{~mm}$ the size of zone of inhibition against $S$. aureus.

In conclusion, this study showed that diosmin inhibited cell proliferation in MDAMB-231 cells in a concentration-dependent and time-dependent manner, without any cytotoxicity against normal human epithelial cells in vitro, and induced apoptosis by increasing the Bax/Bcl-2 ratio as well as active caspase-3 levels. Diosmin was responsible for morphological changes and DNA damage in MDA-MB-231 breast cancer cells. 
However, in vivo studies using animal models of carcinogenesis must be designed, in addition to other in vitro studies, to judge the chemotherapeutic efficacy and clarify the mechanism of action of this flavonoid as a potential prodrug for the treatment of breast cancer. Diosmin may have beneficial effects in the treatment of breast cancer. Of note, diosmin also showed inhibitory and bactericidal activity against only Gram-positive bacteria in the test panel, including MRSA, one of the principal causes of nosocomial infection.

\section{ACKNOWLEDGMENTS}

This work was supported by The Scientific Research Projects Coordination Unit of Akdeniz University; grant number FDK-2018-4039.

\section{CONFLICTS OF INTEREST}

The authors declare no conflict of interest.

\section{REFERENCES}

Androutsopoulos VP, Papakyriakou A, Vourloumis D, Tsatsakis AM, et al. (2010). Dietary flavonoids in cancer therapy and prevention: Substrates and inhibitors of cytochrome P450 CYP1 enzymes. Pharmacol. Therapeut. 126: 9-20.

Athar M, Back HJ, Kopelovich L, Bickers RD, et al. (2009). Multiple molecular targets of resveratrol: anti-carcinogenic mechanisms. Arch. Biochem. Biophys. 486(2): 95-102.

Berqvist D, Hallbrook T, Lindblad B and Lindhagen A (1981). A double blind trial of O-(beta-hydroxy ethyl)rutinosides in patients with chronic venous insufficiency. Vasa. 10: 253-260.

Butler MS and Buss AD (2006). Natural products-The future scaffolds for novel antibiotics? Biochem. Pharmacol. 71: 919-929.

Buddhan R and Manoharan S (2017). Diosmin reduces cell viability of A431 skin cancer cells through apoptotic induction. J. Can. Res. Ther. 13: 471-476.

Camarda L, Di Stefano V, Del Bosco SF and Schillaci D (2007). Antiproliferative activity of citrus juices and HPLC evaluation of their flavonoid composition. Fitoterapia. 78: 426-429.

Celiz G, Daz M, and Audisio MC (2011). Antibacterial activity of naringin derivatives against pathogenic strains. $J$. Appl. Microbiol. 111: 731-738.

Chan BCL, Ip M, Gong H, Lui SL, et al. (2013). Synergistic effects of diosmetin with erythromycin against ABC transporter over-expressed methicillin-resistant Staphylococcus aureus (MRSA) RN4220/pUL5054 and inhibition of MRSA pyruvate kinase. Phytomedicine. 20: 611-614

Choi YK, Seo HS, Choi HS, Kim SR, et al. (2012). Induction of Fas-mediated extrinsic apoptosis, p21WAF1-related G2/M cell cycle arrest and ROS generation by costunolide in estrogen receptor-negative breast cancer cells, MDAMB-231. Mol. Cell Biochem. 363: 119-128.

Clinical and Laboratory Standards Institute (CLSI). (2018). Methods for Dilution Antimicrobial Susceptibility Tests for Bacteria That Grow Aerobically, CLSI Standard M07, 11th Ed., Wayne, PA, Clinical and Laboratory Standards Institute.

Cotelle N, Bernier JL, Catteau JP, Pommery J, et al. (1996). Antioxidant properties of hydroxy-flavones. Free Radical Bio. Med. 20: 35-43.

Crespo ME, Gálvez J, Cruz T, Ocete MA, et al. (1999). Antiinflammatory activity of diosmin and hesperidin in rat colitis induced by TNBS. Planta Med. 65: 651-653.

Dholakiya SL and Benzeroual KE (2011). Protective effect of diosmin on LPS-induced apoptosis in PC12 cells and inhibition of TNF- $\alpha$ expression. Toxicol. in Vitro. 25: 1039-1044.

Dung TD, Lin CH, Binh TV, Hsu HH, et al. (2012). Diosmin induces cell apoptosis through protein phosphatase 2A activation in HA22T human hepatocellular carcinoma cells and blocks tumour growth in xenografted nude mice. Food Chem. 132: 2065-2073.

Ferreira AK, de-Sá-Júnior PL, Pasqualoto KFM, de Azevedo RA, et al. (2014). Cytotoxic effects of dillapiole on MDAMB-231 cells involve the induction of apoptosis through the mitochondrial pathway by inducing an oxidative stress while altering the cytoskeleton network. Biochimie. 99: 195-207.

George VC, Kumar DRN, Suresh PK and Kumar RA (2014). Oleanolic acid inhibits cell growth and induces apoptosis in A375 melanoma cells. Biomed. Prev. Nutr. 4: 95-99. 
George VC, Kumar DRN, Suresh PK and Kumar S (2012). Apoptosis-Induced Cell Death due to Oleanolic Acid in HaCaT Keratinocyte Cells -a Proof-of-Principle Approach for Chemopreventive Drug Development. Asian Pac. J. Cancer P. 13: 2015-2020.

George VC, Kumar DRN, Suresh PK, Kumar S et al. (2013). Comparative Studies to Evaluate Relative in vitro Potency of Luteolin in Inducing Cell Cycle Arrest and Apoptosis in HaCaT and A375 Cells. Asian Pac. J. Cancer P. 14(2): 631-637.

Germoush MO (2016). Diosmin protects against cyclophosphamide-induced liver injury through attenuation of oxidative stress, inflammation and apoptosis. Int. J. Pharmacol. 12: 644-654.

Hafidh RR, Abdulamir AS, Abu Bakar F, Jalilian FA, et al. (2013). Novel anticancer activity and anticancer mechanisms of Brassica oleracea L. var. capitata f. Rubra. Eur. J. Integr. Med. 5: 450-464.

Hayek SA, Gyawali R and Ibrahim SA (2013). Antimicrobial natural product. In: Microbial pathogens and strategies for combating them: Science, technology and education (Mendez-Vilas A, ed.). Formatex Research Center.

Jemal A, Bray F, Center MM, Ferlay J, et al. (2011). Global cancer statistics. CA Cancer J. Clin. 61: 69-90.

Kim YM, Tsoyi KH, Jang J, Park EK, et al. (2014). CKD712, a synthetic isoquinoline alkaloid, enhances the anti-cancer effects of paclitaxel in MDA-MB-231 cells through regulation of PTEN. Life Sci. 112: 49-58.

Köse EO, Öngüt G and Yanikoglu A (2013). Chemical Composition and Antimicrobial Activity of Essential Oil of Endemic Origanum bilgeri PH Davis for Turkey. J. Essent. Oil-Bear. Plants 16(2): 233-242.

Kumar DRN, George VC, Suresh PK and Kumar RA (2012). Cytotoxicity, Apoptosis Induction and Anti-Metastatic Potential of Oroxylum indicum in Human Breast Cancer Cells. Asian Pac. J. Cancer P. 13: 2729-2734.

Lam KS (2007). New aspects of natural products in drug discovery. Trends Microbiol. 15(6): 280-289.

Li H, Yang B, Huanga J, Xiang T, et al. (2013). Naringin inhibits growth potential of human triple-negative breast cancer cells by targeting $\beta$-catenin signaling pathway. Toxicol. Lett. 220: 219-228.

Li Z, Li J, Mo B, Hu C, et al. (2008). Genistein induces cell apoptosis in MDA-MB-231 breast cancer cells via the mitogen-activated protein kinase pathway. Toxicol. in Vitro. 22: 1749-1753.

Livak KJ and Schmittgen TD (2001). Analysis of relative gene expression data using real-time quantitative PCR and the 2(-Delta Delta C (T)) Method. Methods. 25(4): 402-408.

Manthey J and Guthrie N (2002). Antiproliferative Activities of Citrus Flavonoids against Six Human Cancer Cell Lines. J. Agr. Food Chem. 50: 5837-5843.

Manuel Y, Keenoy B, Vertommen J and De Leeuw L (1999). The effect of flavonoid treatment on the glycation and antioxidant status in type 1 diabetic patients. Diabetes Nutr. Metab. 12: 256-263.

Marchand L, Le Murphy SP, Hankin JH, Wilkens LR, et al. (2000). Intake of flavonoids and lung cancer. J. Natl. Cancer. I 92: 154-160.

Nikhil K, Sharan S, Chakraborty A and Roy P (2014). Pterostilbene-Isothiocyanate Conjugate Suppresses Growth of Prostate Cancer Cells Irrespective of Androgen Receptor Status. PLoS one. 9(4): 1-16.

Olenyuk BZ, Zhang GJ, Klco JM, Nickols NG, et al. (2004). Inhibition of vascular endothelial growth factor with a sequence-specific hypoxia response element antagonist. Proc. Natl. Acad. Sci. U.S.A. 101(48): 16768-16773.

Orhan DD, Özçelik B, Özgen S and Ergun F (2010). Antibacterial, antifungal, and antiviral activities of some flavonoids. Microbiol. Res. 165: 496-504.

Papi A, Farabegoli F, Iori R, Orlandi M, et al. (2013). Vitexin-2-O-xyloside, raphasatin and (-)-epigallocatechin-3gallate synergistically affect cell growth and apoptosis of colon cancer cells. Food Chem. 138: 1521-1530.

Pedro M, Lourenço CF, Cidade H, Kijjoa A, et al. (2006). Effects of natural prenylated flavones in the phenotypical ER (+) MCF-7 and ER (-) MDA-MB-231 human breast cancer cells. Toxicol. Lett. 164: 24-36.

Ravishankar D, Rajora AK, Greco F and Osborn HMI (2013). Flavonoids as prospective compounds for anti-cancer therapy. Int. J. Biochem. Cell B. 45: 2821- 2831.

Rehman MU, Tahir M, Khan AQ, Khan R, et al. (2013). Diosmin protects against richloroethylene-induced renal injury in Wistar rats: plausible role of p53, Bax and caspases. Brit. J. Nutr. 110: 699-710.

Ruddock PS, Charland M, Ramirez S, Lo'pez A, et al. (2011). Antimicrobial Activity of Flavonoids from Piper lanceaefolium and Other Colombian Medicinal Plants Against Antibiotic Susceptible and Resistant Strains of Neisseria gonorrhoeae. Sex. Transm. Dis. 38(2): 82-88.

Sahu N, Soni D, Chandrashekhar B, et al. (2016). Synthesis of silver nanoparticles using flavonoids: hesperidin, naringin and diosmin, and their antibacterial effects and cytotoxicity. Int. Nano. Lett. 6: 173-181.

Sakamoto T, Horiguchi H, Oguma E and Kayama F (2010). Effects of diverse dietary phytoestrogens on cell growth, cell cycle and apoptosis in estrogen-receptor-positive breast cancer cells. J. Nutr. Biochem. 21: 856-864.

Sato Y, Suzaki S, Nishikawa T, Kihara M, et al. (2000). Phytochemical flavones isolated from Scutellaria barbata and antibacterial activity against methicillin-resistant Staphylococcus aureus. J. Ethnopharmacol. 72: 483-488.

Shang D, Liu Y, Liu Q, Zhang F, et al. (2009). Synergy of 5-aza-20-deoxycytidine (DAC) and paclitaxel in both androgen-dependent and -independent prostate cancer cell lines. Cancer Lett. 278: 82-87.

Silambarasan T and Raja B (2012). Diosmin, a bioflavonoid reverses alterations in blood pressure, nitric oxide, lipid peroxides and antioxidant status in DOCA-salt induced hypertensive rats. Eur. J. Pharmacol. 67: 81-89.

Silva NCC and Fernandes Júnior AJJOVA (2010). Biological properties of medicinal plants: a review of their antimicrobial activity. J. Venom Anim. Toxins incl. Trop. Dis. 16(3): 402-413. 
Singh DV, Agarwal S, Singh P, Godbole MM et al. (2013). Curcumin Conjugates Induce Apoptosis via a Mitochondrion Dependent Pathway in MCF-7 and MDA-MB-231 Cell Lines. Asian Pac. J. Cancer P. 14(10): 5797-5804.

Smith PD (1999). Neutrophil activation and mediators of inflammation in chronic venous insufficiency. J. Vasc. Res. 36: 24-36.

Sohn HY, Son KH, Kwon CS, Kwon GS, et al. (2004). Antimicrobial and cytotoxic activity of 18 prenylated flavonoids isolated from medicinal plants: Morus alba L., Morus mongolica Schneider, Broussnetia papyrifera (L.) Vent, Sophora flavescens Ait and Echinosophora koreensis Nakai. Phytomedicine. 11: 666-672.

Srinivasan S and Pari L (2012). Ameliorative effect of diosmin, a citrus flavonoid against streptozotocin nicotinamide generated oxidative stress induced diabetic rats. Chem-Biol. Interact. 195: 43-51.

Tahir M, Rehman MU, Lateef A, Khan R, et al. (2013). Diosmin protects against ethanol-induced hepatic injury via alleviation of inflammation and regulation of TNF- $\alpha$ and NF-kB activation. Alcohol. 47: 131-139.

Tanaka T, Makita H, Kawabata K, Mori H, et al. (1997). Modulation of N-methyl-N-amylnitrosamine-induced rat oesophageal tumourigenesis by dietary feeding of diosmin and hesperidin, both alone and in combination. Carcinogenesis. 18: 761-769.

Vonthron-Sénécheau C, Weniger B, Ouattara M, Tra Bi F, et al. (2003). In vitro antiplasmodial activity and cytotoxicity of ethnobotanically selected Ivorian plants. J. Ethnopharmacol. 87(2-3): 221-225.

Wang CD, Yuan CF, Bu YQ, Wu XM, et al. (2014). Fangchinoline Inhibits Cell Proliferation Via Akt/GSK-3beta/cyclin D1 Signaling and Induces Apoptosis in MDA-MB-231 Breast Cancer Cells. Asian Pac. J. Cancer P. 15(2): 769773.

Wendakoon C, Calderon P and Gagnon D (2012). Evaluation of Selected Medicinal Plants Extracted in Different Ethanol Concentrations for Antibacterial Activity against Human Pathogens. J. Med. Act. Plant. 1(2): 60-68.

Yang S, Zhou Q and Yang X (2007). Caspase-3 status is a determinant of the differential responses to genistein between MDA-MB-231 and MCF-7 breast cancer cells. Biochim. Biophys. Acta. 1773: 903-911.

Yuan JS, Reed A, Chen F and Jr. Stewart CN (2006). Statistical analysis of real-time PCR data. BMC Bioinformatics. 7: 85 .

Zhang, H, Ke J, Shao T, Li J, et al. (2014). Cytotoxic effects of procyanidins from Castanea mollissima Bl. Shell on human hepatoma G2 cells in vitro. Food Chem. Toxicol. 64: 166-176.

Zordoky BNM, Bark D, Soltys CL, Sung MM, et al. (2014). The anti-proliferative effect of metformin in triple-negative MDA-MB-231 breast cancer cells is highly dependent on glucose concentration: Implications for cancer therapy and prevention. Biochim. Biophys. Acta. 1840: 1943-1957. 